\title{
Deforestation governance in the Amazon from a Strategic Action Fields perspective
}

${ }^{1}$ Universidade Federal do Maranhão, São Luís, MA, Brasil.

${ }^{\text {II }}$ Universidade Federal do Pará, Belém, PA, Brasil.

III Universidade Federal do Maranhão, São Luís, MA, Brasil.

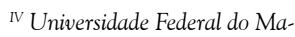
ranhão, São Luís, MA, Brasil.

\author{
Marcelo Sampaio Carneiro \\ William Santos Assis \\ Ulisses Denache Vieira Souza \\ Lidielze Dourado
}

\begin{abstract}
The article seeks to analyze the development of deforestation governance actions in the Amazon, based on the analysis of two case studies using the Strategic Action Fields theory (FLIGSTEIN; MCADAM, 2012). It analyzes the experience of mobilization for the removal of the city of Paragominas/PA from the deforestation Black List and the development of deforestation control actions in the São Jorge settlement, in the city of Cidelândia / Maranhão. Interviews with main actors and satellite images were used to analyze the two cases. The results indicate the relevance of using the Strategic Action Fields theory to gain an understanding of deforestation governance processes in the Amazon, highlighting the importance of central concepts to this theory, such as the performance of skilled social actors and the construction of internal units of governance.
\end{abstract}

Keywords: Deforestation; Governance; Strategic Action Fields; Amazon.

São Paulo. Vol. 23, 2020

Original Article

DOI: http://dx.doi.org/10.1590/1809-4422asoc20180247r2vu2020L5AO 


\section{Introduction}

In the years from 2004 to 2011 there was an almost uninterrupted reduction in the deforestation rate in the Brazilian Amazon resulting from the conjugation of various kinds of action undertaken by agents of the State and civil society, involving modifications in the legislation, command and control actions and the use of market mechanisms (CEPAL/IPEA/GIZ, 2011; NEPSTAD et al., 2008).

When describing that process, many authors have used the concept of governance; a concept that emerged to embrace the new patterns of government action (LASCOUMES; LE GALÉS, 2009) in the face of problems that called for multi-scale, inter-sector and even transnational performances (MICHELETTI, 2004). More recently, some of the academic works have begun to use the theory of strategic action fields (SAF) (FLIGSTEIN; MCADAM, 2012) to understand the constitution and functioning of such Amazon deforestation mechanisms (AMARAL, 2017; FRIZO, 2018). They underscore the central elements as being the performances of skillful social actors and the construction of internal governance units that make it possible to achieve the construction and stabilization of collective agreements on the management and use of natural resources.

Our article works in a similar perspective and aims to discuss deforestation governance actions in two different experiences, both situated in the eastern Amazon. To that end it analyzes the experience of a mobilization designed to get the municipality of Paragominas, in the state of Pará, removed from the aegis of the Edict for the Inclusion of New Municipalities on the List of Priority Areas for the Prevention and Control of Deforestation in the Legal Amazon (Portaria de Inclusão de Novos Municípios na Lista de Áreas Prioritárias para a Prevenção, Controle do Desmatamento na Amazônia Legal) more popularly known as the 'deforestation black list', and the process of deforestation control in the São Jorge settlement located in the municipality of Cidelândia in the micro-region of Imperatriz in the state of Maranhão (CARNEIRO, 2015).

Although they are experiences developed in different spatial scales (municipality and settlement), the element that unites these two case studies of the municipality of Paragominas (Pará) and São Jorge settlement (Maranhão) is the roles played by internal governance units and skillful social actors (FLIGSTEIN; MCADAM, 2012) in constructing agreements that make it possible to control deforestation dynamics. In other words, as Paugam and Van de Velde (2015, p.296) argue, underscoring the potentialities of using comparative analysis in sociological research does not mean "comparing the incomparable or confronting the overly similar, but, instead, confronting different configurations of the phenomenon in question" in such a way as to highlight the connection between certain given aspects of the study object.

After this Introduction the article is divided into three sections and the Conclusion. In the first section we make a succinct presentation of the main elements of the theoretical reference adopted, namely, the theory of strategic action fields (FLIGSTEIN, 2011; FLIGSTEIN; MCADAM, 2012); in the second section we portray the experience of the Município Verde (Green Municipality) Project in Paragominas; while in the third we analyze the case of deforestation control in the São Jorge Settlement. 
In the presentation of the case analyses that provide the basis for our argumentation we will also present the context in which they developed and then highlight the process that constituted the internal governance units and the role played by certain social actors in the construction of the agreements that originated the deforestation governance practices in the two situations.

Prior to that, however, we will highlight the methodological procedures used for gathering and analyzing the data on which the article is based.

The case studies presented here stem from two different research projects. Data gathering for the study of deforestation governance in Paragominas began in 2011 and finalized in $2013^{1}$. In that period we made three trips to the municipality where we interviewed local government administrators, union leaders, businessmen (cattle farmers and loggers), representatives of NGOs active in the locality (TNC and Imazon) and research institutions (EMBRAPA).

Data gathering for the study of the São Jorge settlement began later, in 2015, and is still in course ${ }^{2}$ (CARNEIRO et al., 2020). For the latter research we conducted four survey and data gathering campaigns during which we interviewed settlement leaders, union leaders and technical staff of the NGO that provides technical assistance to the settlers, the Rural Workers Training and Education Center (Centro de Treinamento e Educação do Trabalhador Rural - CENTRU). We also administered a questionnaire to 20 settlers and held a workshop to discuss participative mapping techniques (DOURADO et al., 2017).

During the workshop and the field surveys, information was collected to produce maps that would enable us to understand the alterations that had been taking place in the evolution of land use and occupation in the settlement area. That procedure was unnecessary for Paragominas as the evolution of land use and settlement for that municipality has already been thoroughly studied (SILVA et al., 2017; SOUSA et al., 2017).

Analysis of land use at the São Jorge settlement involved a temporal comparison based on the extraction of information from Landsat 5 images for the years 1990, 2000 and 2010 and Landsat 8 images for the year 2017. The first set of images analyzed was for the year 1990 which was defined as the base line data representing the period prior to the occupation of the former São Jorge farm. The second set was for the year 2000, five years after the effective process of dividing the land into plots for the settlers took place, which was in 1995. The third and fourth sets of images selected for analysis corresponded to the years 2010 and 2017 with the intention of identifying more recent modification processes in land use patterns in the settlement area.

The Landsat images were chosen because they have a temporal series with per-

1- This research received financial support from: The National Council for Scientific and Technological Development (Conselho Nacional de Desenvolvimento Científico e Tecnológico - CNPQ) (Edital Ciências Humanas n. 02/2010); and the Maranhão Research Support Foundation (Fundação de Amparo à Pesquisa do Maranhão - FAPEMA) (Edital Universal n. 01/2013).

2 - This research was supported by grants of the calls for research process of the Coordinating Body for the Qualification of Higher Personnel (Coordenação de Aperfeiçoamento de Pessoal de Nível Superior - CAPES) (Edital PGPSE n. 42/2014); and the Maranhão Research Support Foundation (Fundação de Amparo à Pesquisa do Maranhão - FAPEMA) (Edital Universal n. 31/2016). 
manent characteristics (spatial resolution of $30 \mathrm{~m}$ and bands in the near-infrared) and because they present a cloud cover of less than $10 \%$ per image quadrant; an important feature that made it possible to analyze the evolution of ground cover patterns ${ }^{3}$.

The analysis of land use evolution was based on the following classes of interest: a) areas of dense vegetation (includes areas of forest, gallery forest and arboreal vegetation with some tall trees); b) Areas in regeneration (fragments of images presenting intermittent patches of vegetation, arboreal vegetation and areas of non-dense thicket vegetation); c) Agricultural areas (with crop cultivation being developed); c) exposed soil (areas with the characteristics of fields prepared for crop planting, with the soil exposed or recently deforested with clear-cut felling and clearance of terrain) and lastly, e) Bodies of water (usually reservoirs or small streams).

\section{The Theory of Strategic Action Fields and its application to the analysis of deforestation governance}

According to Fligstein and McAdam (2012), the aim of developing the Theory of Strategic Action Fields was to gain an understanding as to how certain actors engage in collective actions based on the skills they possess within given social contexts (fields) and to show how they struggle to try and stabilize or transform that same social field.

The factor that differentiates this theory, elaborated in discussion with the Field Theory of Bourdieu (2000), is the weight it attributes to the so-called social skills in the process of struggles for change or for maintenance of a given field of strategic action FLIGSTEIN; MCADAM, 2012, p.16). According to Fligstein (2011, p.171), the "definition of social skill emphasizes how certain individuals are endowed with a highly developed cognitive capacity to evaluate people and environments, establishing lines of action and mobilizing people in accordance with those action structures".

The existence of agents with social skills is central to understanding the formation of social coalitions interested in maintaining or in changing a given social field. That leads us to another important concept that this theory has developed, equally central to the comprehension of the cases of deforestation control being addressed here, which is the concept of internal governance units. According to the authors, the concept designates "the existence of associations or organizations within a given field whose main function is to guarantee routine stability and order in the strategic action field" FLIGSTEIN; MCADAM, 2012, p. 77).

Changes occur in an SAF when skillful actors manage to constitute coalitions that overcome their adversaries. For that to happen however, it is also necessary to take into account the role played by other fields in that process, that is, the broader context in which the field of analysis is situated, its relations with the State field and with other

3. Field work was undertaken to assist the gathering of information on environmental management in the settlement and the respective data points were georeferenced. 
fields that are important for the analysis in question ${ }^{4}$, as happens, metaphorically, in that authors' example of the 'Russian doll' (FLIGSTEIN; MCADAM, 2012, p. 204).

In the two cases that will be discussed below we endeavor to show how the relative success achieved in combating deforestation in the experiences of the Green Municipality Project of Paragominas (Pará) and the São Jorge settlement (Maranhão) can be explained by the ability of certain social actors to constitute a coalition of actors in favor of introducing measures to control deforestation and to institute an internal unit of governance, respectively in the municipality and in the settlement in question.

It must be pointed out that in the case of Paragominas what is involved is the emergence of an SAF to establish a pattern of deforestation governance that was motivated by the action of State agents (external shock) whereas in the case of the São Jorge settlement, what is in question is the maintenance of a pattern of land use and settlement established in the course of the settlement process. In other words, what is being analyzed is the capacity to maintain the governance practice norms (DE SARDAN, 2008) regarding deforestation in the settlement.

\section{Deforestation governance in a municipality: the experience of the Município Verde Project in Paragominas/Pará.}

\subsection{The context in which the Município Verde Project emerged}

The factor that led to the deforestation governance experience in Paragominas was the Ministry of the Environment's publication, in January 2008, of the first "Deforestation Blacklist" (FERNANDES, 2011). The list was one of a set of measures that the federal Government implemented in an endeavor to reduce deforestation in the region under the aegis of the Action Plan for Prevention and Control of Deforestation in the Legal Amazon (Plano de Ação para a Prevenção e o Controle do Desmatamento na Amazônia Legal - PPCDAm). Once a municipality had been inscribed in the Black List it became the object of a series of actions, the most important of which were: a) articulation of environmental and land tenure regularization actions by means of a re-registration of rural properties; b) credit restriction for rural properties under embargoes; and c) compulsory embargos on illegally deforested areas (LIMA et al., 2008).

Of the set of actions associated to the 'Black List', restricting access to credit was possibly the one that most affected Paragominas's economic elite because the statements made by important municipal leaders show that the local agricultural and livestock raising activities were highly dependent on official credit. Former mayor Adnan Demarchki declared that in his opinion "two thirds of producers in Paragominas finance their activities via the Banks, above all via the Bank of Amazonas (Banco da Amazônia - Basa)" (BARROS, 2012, p. B-16). The President of the Association of Soy, Rice and Maize

4 - According to Fligstein and McAdam (2012, p.18), there are fields that are nearer and others farther away, fields that are dependent and others, independent; state fields and non-state fields. Lastly it is necessary to consider the State as being "a dense collection of fields". 
Producers in Paragominas, Michel Cambri confirmed that statement when he said that about $50 \%$ of them financed their crop planting and harvesting costs based on bank financing (BARROS, 2010, p. B-16).

According to SAF theory, the dominant political-economic coalition in the municipality, made up of cattle farmers, loggers and soy bean crop farmers (CARNEIRO; ASSIS, 2015), was challenged by an action stemming from a nearby field, that is, the federal government field, which, by means of the imposition of a restriction on credit motivated the municipality's dominant actors to make a move.

Faced with that situation, local political leaders, alongside the leading civil society entities, took the initiative of articulating a reaction with a view to getting the municipality off the list of those in a critical situation in regard to deforestation. According to Adnan Demarchki, at a meeting held in the City Hall auditorium on February 28, 2008, a pact for the control of deforestation in the municipality was launched.

So, at a meeting that lasted four hours we established a pact, didn't we. There were 51 entities present: unions, associations, service clubs, all the municipality's economic sectors and the 10 councilors, so then we signed a pact on that day: the 'Zero Deforestation pact'. (Interview with A.D. conducted on August 8, 2012, Paragominas).

The central objective of the Zero Deforestation Pact was the establishment of a commitment not to carry out any new deforestation actions in the municipality.

To ensure the feasibility of monitoring that commitment, the city hall requested the support of the Amazon Man Institute (Instituto do Homen da Amazônia - IMAZON) - a non-governmental organization with a broad background of research in the municipality - and articulated with the state government: the signing of: a Term of Decentralized Administration which transferred some of the powers regarding environmental licensing and inspection/surveillance to the Municipal Department of the Environment; and a Term of Technical Cooperation aimed at carrying out "actions associated to the Municipal Plan for Fighting and Preventing Deforestation (Plano Municipal de Prevenção e Combate ao Desmatamento)" (LUCENA, 2011, p. 90)..

According to the person who was the mayor at the time, in the first few months of Pact execution the main economic activity stimulating deforestation was the production of charcoal to supply the blast furnaces of the ironworks in Marabá/Pará and Açailândia/ Maranhão. In addition to the shock with that sector there was another with the illegal activity of logging in the indigenous reserve of Alto Rio Guamá (Upper Guamá River) which continued uncontrolled. To counter these and other kinds of environmentally illegal activity, in November 2008 the federal government unfolded a second operation in the municipality entitled Arca do Fogo (Arc of Fire).

This second operation, 'Arca de Fogo', had strong repercussions in the media as the loggers whose equipment had been seized (trucks, tractors etc.) organized a mobilization to recover them and threatened to set fire to the hotel where the inspectors of the Brazilian Institute for the Environment and Renewable Natural Resources (Instituto Brasileiro do Meio Ambiente e Recursos Naturais Renováveis - IBAMA) were accommodated. It was the most serious challenge to the Zero Deforestation Pact proposal. In the opinion of the 
mayor at that time, the situation of the municipal economy, debilitated by the employment resulting from the confrontation of the irregular activities, together with the authoritarian manner in which the Arca de Fogo operation was unfolded left local civil society divided as to whether the Pact should continue or not (CARNEIRO, ASSIS, 2015).

To address the new situation, the municipal government elaborated a document to present to the Ministry of the Environment, setting out the details of the Green $\mathrm{Mu}$ nicipality (Município Verde) project. The document was written in the form of a Charter of Commitment (LUCENA, 2011), which, in addition to reinforcing the previous commitment to deforestation control, proposed the development of economic activities that could be considered sustainable.

The President of the Paragominas Rural Producers Union (Sindicato dos Produtores Rurais - SPR) also stressed the importance of adherence to that Charter of Commitment in the construction of a strategy to get the municipality off the deforestation blacklist. In his view, the incident regarding setting fire to the Ibama office represented a milestone in the construction of the Green Municipality proposal because "that act of vandalism demanded a greater commitment on our part" and that materialized in the form of the 'Paragominas: Green Municipality' project (Mauro Lúcio/ Paragominas SPR, interview conducted on August 6, 2012, Paragominas-Pará).

The mobilization around the Green Municipality project had the desired effect and, as various studies have demonstrated, it was successful in obtaining control of deforestation in the municipality; so much so that on March 24, 2010 an Edict of the Ministry of the Environment removed Paragominas from the Deforestation Blacklist (CARNEIRO; ASSIS, 2015; SOUSA et al., 2017; COSTA; FLEURY, 2018).

In the Figure 1 and the table 1 below elaborated on the basis of an analysis of satellite images, we would highlight the deforestation control process in Paragominas taking as our reference the evolution of the five classes of land use in the three time frames: at the beginning of the century (2000); at the moment when the municipality got off the Deforestation Blacklist (2010); and seven years after the implantation of the Green Municipality Project (2017).

Table 1 - Evolution of the participation of land use classes in the municipality of Paragominas - 2000/2010/2017.

\begin{tabular}{|c|c|c|c|c|c|c|}
\hline \multirow{2}{*}{ CLASSES/YEAR } & \multicolumn{2}{|l|}{2000} & \multicolumn{2}{|l|}{2010} & \multicolumn{2}{|l|}{2017} \\
\hline & ha & $\%$ & ha & $\%$ & ha & $\%$ \\
\hline Dense Vegetation & $1,477,479.27$ & 76.39 & $1,323,603.19$ & 68.43 & $1,314,737.40$ & 67.97 \\
\hline Agricultural Area & $413,580.68$ & 21.38 & $555,188.63$ & 28.70 & $550,558.23$ & 28.46 \\
\hline $\begin{array}{l}\text { Area in Regenera- } \\
\text { tion }\end{array}$ & $35,344.50$ & 1.83 & $46,275.24$ & 2.39 & $58,155.48$ & 3.01 \\
\hline Exposed Soil & $1,622.46$ & 0.08 & $2,782.64$ & 0.14 & $4,306.77$ & 0.22 \\
\hline
\end{tabular}



Body of Water
$6,206.02$
0.32
$6,383.24$
0.33
$6,475.06$
0.33

Source: Landsat 05 - 08 / USGS Images.

It can be seen that there was a considerable reduction in the land use class 'Dense Vegetation' (Forest) between the years 2000 and 2010 with the loss of around 154 thousand hectares whereas in the subsequent interval (2010 to 2017) the reduction was only slight, around 8.8 thousand hectares. The agricultural area presented a similar pattern with a strong increment in the first period (2000 to 2010) of around 142 thousand hectares and a reduction in the following period ( -5 thousand hectares $)^{5}$.

Thus, as similar studies have shown (SOUSA et al., 2017; SILVA et al., 2017), after the mobilization process associated to the Green Municipality Project there was a stabilization in the reduction of forested areas in the municipality in spite of the increase in the areas of crop land (soy) which occurred mainly through the conversion of pastureland.

Figure 1 - Evolution of land use classes in the municipality of Paragominas.

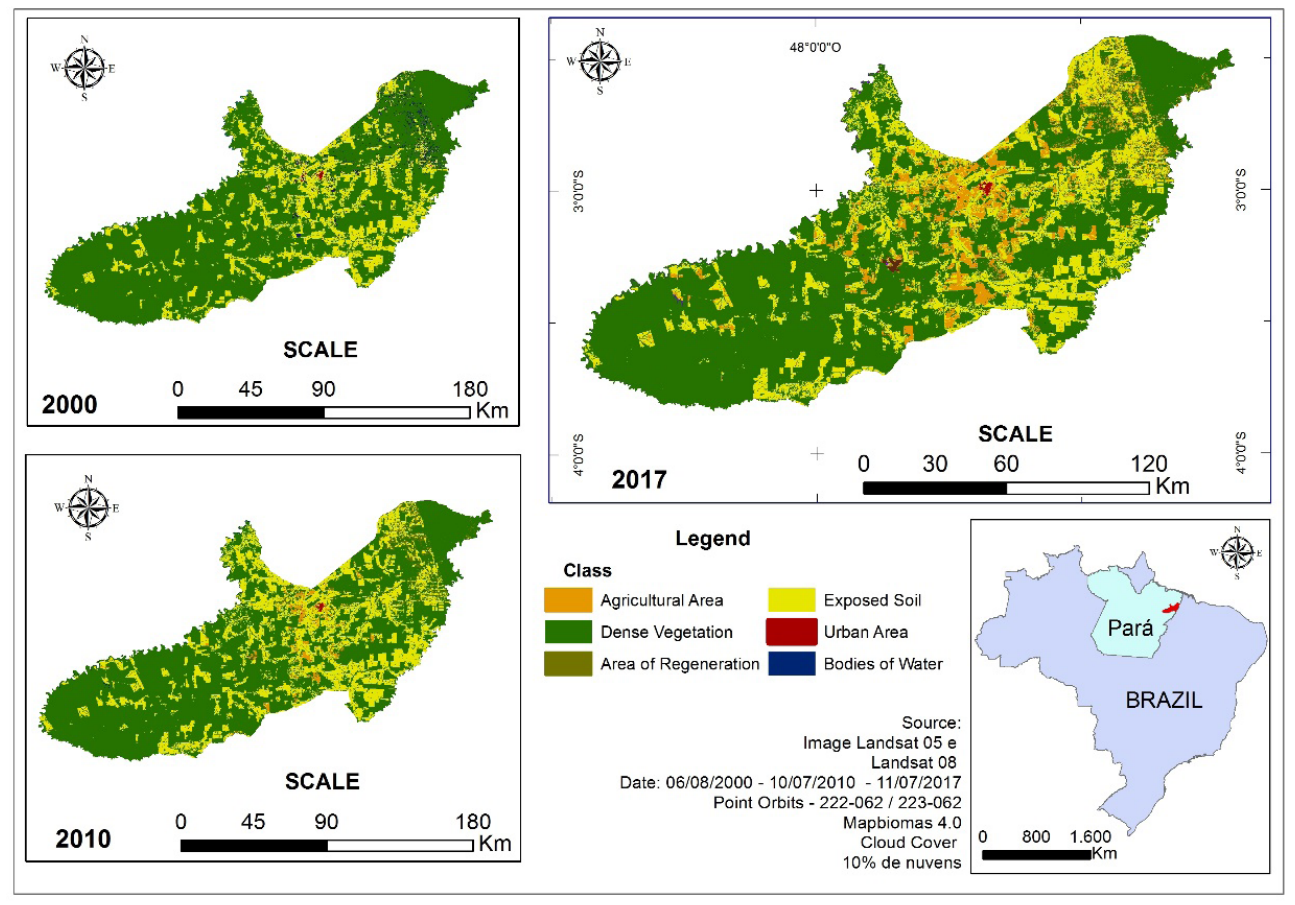

Source: Landsat 05 - 08 / USGS and MapBiomas project 4.0.

5 - Considering a broader timeframe we find that the municipality's deforestation rate went from an average of 147.15 $\mathrm{km}^{2} /$ year in the period 2001 to 2009 , to an average of $28.33 \mathrm{~km}^{2} /$ year from 2010 to 2018 , according to PRODES data. 


\subsection{The skillful social actors and the construction of the deforestation governance devices $o$}

As we pointed out in the first section of this article, the theory of SAFs focuses attention on the role that skillful social actors play in the construction of political coalitions, making other actors cooperate in the development of certain lines of action (FLIGSTEIN; MCADAM, 2012, p.202). In the case of the Paragominas: Green Municipality project, that role was performed by two actors: the mayor Adnam Demachki and the president of the Paragominas SPR, Mauro Lúcio. Both were local leaders belonging to the political group of the Brazilian Social Democracy Party (Partido da Social Democracia Brasileira - PSDB) which had consecutively won the six preceding municipal government elections and conducted the municipal executive branch of Paragominas (CARNEIRO; ASSIS, 2015).

The role of those two actors was crucial in overcoming the resistance of the businessmen of the logging and cattle raising sectors who had supported the action unleashed against the Ibama employees on the occasion of the Arca de Fogo operation in 2008. At the same time they headed the process to construct deforestation governance instruments with the implementation of Rural Environmental Registration (Cadastro Ambiental Rural - CAR $)^{6}$ and monitoring of deforestation in the municipality by means of partnership arrangements established with two non-governmental organizations: the Amazon Man Institute (Instituto do Homem da Amazônia - IMAZON) and The Nature Conservancy (TNC).

The elaboration of the CAR was boosted by the performance of the TNC in the mobilization in favor of the Green Municipality. The TNC began its work in Paragominas in 2009 after having been invited by the City Hall and the Rural Producers Union to carry out the Rural Producers Registration of large and medium-sized landowners and to do so with financial resources obtained by means of projects supported by the Vale Pro-Sustainable Development Fund (Fundo Vale para o Desenvolvimento Sustentável) and the United States Agency for International Development (USAID). Thus, in 2009, the work carried out by the TNC together with the Paragominas SPR made it possible to satisfy one of the criteria established for being removed from the list of municipalities considered priority for combating deforestation, namely, the environmental registration of more than $80 \%$ of the rural properties. Currently, according to data of the Pará State government, $92.80 \%$ of the area subject to registration in the municipality has been duly registered as can be seen from the information made available of the Summary page of the Official Page of the State Green Municipalities Program; only the agrarian reform settlements have yet to be registered.

In the ambit of the mobilization in favor of the Green Municipality project, the performance of Imazon, an organization that has been conducting research in Paragominas (Pará) ever since the 1990s (ALMEIDA, 1996), can best be described on the basis of two aspects: the advisory services it provided to the municipal authority in the elaboration of the Municipal Plan for Combating Deforestation (DEMACHKI, ZAGALO NETO, 
2008), and the monitoring of deforestation in the municipality by publishing bulletins of the Deforestation Warning System (BARRETO; ARAÚJO, 2012).

We can safely say that with the institution of the State Green Municipalities Program (Programa Estadual dos Municípios Verdes - PEMV) in 2011 (COSTA; FLEURY, 2015), deforestation governance in Paragominas was formalized at two levels. At the first level, of a local nature, it was formalized by means of the Paragominas Environmental Observatory made up of representatives of: the Offices of the State and Federal Public Prosecutors, IBAMA, the State Government Department of the Environment, IMAZON, the TNC, the Paragominas SPR, the Paragominas City Council, and the Paragominas Municipal Council for the Defense of the Environment. At another level, in the external environment, it was formalized by means of the municipality's adherence to the requirements of the PEMV, whose department monitors compliance. In other words, we can say that the Environmental Observatory functions as an internal governance unit albeit that governance is monitored by its compliance with PEMV targets/goals.

\section{Deforestation governance in an agrarian reform settlement; the case of the São Jorge settlement}

Although they cannot be accused of being the main protagonists of deforestation in the Amazon, from the year 2008 on the settlements began to make an important contribution to that process. A study conducted by Alencar et al. (2016) shows that most of that deforestation occurred in traditional settlements created in the 1990s. The case of the settlement being studied here falls within that general dynamics because it is a settlement of the more traditional type created by the National Settlement and Agrarian Reform Institute (Instituto Nacional de Colonização e Reforma Agrária - Incra) in 1997 even though the São Jorge property had actually been occupied in 1991.

However, unlike most of the settlements created in the Eastern Amazon region, the occupation of the São Jorge lands was marked by concern to make the agricultural activities of the settlers compatible with an environmental preservation strategy and the main initiatives in that direction were: the constitution of a collective legal reserve area, the effective preservation of areas of permanent protection and the development of Agro-Forestry Systems (Sistemas Agroflorestais) as we will show below.

\subsection{The context in which the São Jorge settlement was constituted}

The São Jorge farm was a property dedicated to livestock and crop production located in what was at the time the municipality of Imperatriz (Maranhão) but nowadays is the municipality of Cidelândia (Maranhão).It was originally occupied by families organized by the Imperatriz Union of Men and Women Rural Workers (Sindicato de Trabalhadores e Trabalhadoras Rurais - STTR) together with the non-governmental 
organization CENTRU ${ }^{7}$, an entity with a strong and active presence in the west of Maranhão state that sought to make agrarian reform actions compatible with environmental preservation (SANTOS, 2010).

According to the statements of the settlers, even though the occupation occurred in 1991, it was only in 1995 that the area was divided up into lots and that was two years prior to the settlement's official creation by the Incra. In that process of division and concession of 50 hectare lots to each family of occupants, it was determined that there should be a collective area of preserved forest (área de reserva florestal coletiva - ARFC) of 232.40 hectares in order to maintain the habitat of the fauna and flora in the region (IICA, 2006).

The establishment of that ARFC in the settlement had a lot to do with the work of the CENTRU which provided technical assistance right from the moment when the São Jorge property was first occupied and was active in promoting Agro-forestry systems and extractive agriculture together with the Association of Rural Smallholders of the São Jorge Settlement (Pequenos Produtores Rurais do Assentamento São Jorge-ASPRAJORGE), an entity created to represent the São Jorge settlement residents.

It should be stressed, however, that the settlers' delimitation of that ARFC must not be confused with the act of complying with the legal requirement for the establishment of Legal Reserve Areas determined by the Forest Law in force which would have meant immobilizing $80 \%$ of the total settlement area; something that not even the Incra demanded in settlement-instituting processes in the 1990s (KOWARICK, 2011).

In addition to CENTRU support, the defense of preservationist practices was boosted by actions in the settlement of the Project for the Mobilization and Capacitation of Family, Extractive and Indigenous Farmers for the Prevention of Forest Fires in the Amazon (PROTEGER is the acronym in Portuguese) ${ }^{8}$ which included courses on fire management and the creation of a fire-fighting brigade in an endeavor to raise settlers' awareness in regard to the dangers of fires and the need to do any eventual burning in a controlled manner (SAUER, 2005).

In addition to the Proteger project, the CENTRU unfolded other initiatives in the Imperatriz region that helped towards the development of more sustainable production processes, such as the Frutos do Cerrado (Fruits of the Cerrado) project implanted through a partnership arrangement with the Indigenist Training Center (Centro de Treinamento Indigenista - CTI) and the project Alternative sustainable agro-extractivism in solidarity with the peoples of the Maranhão cerrado (Agroextrativismo: alternativa sustentável e solidária aos povos do cerrado maranhense), supported by Petrobrás (NÓBREGA, 2015).

More recently, the Asprajorge has carried out actions to foster the development of

7 - The CENTRU was created by Manoel da Conceição, an important Brazilian rural workers leader who was persecuted and exiled by the military dictatorship but returned in the 1980s and began to carry out grassroots education work (NÓBREGA, 2015).

8 - The Proteger Project was an initiative elaborated by the Federal Government to be implemented by Ibama and designed to unfold "prevention, surveillance and control of burning and to combat forest fires in the so-called Arc of Deforestation in the Amazon" (SAUER, 2005). 
Agro-forestry systems, endeavoring to value the cultivation of local fruits (Jussara, Bacuri etc.) with financial resources provided by the Small Ecosocial Projects Program (Programa Pequenos Projetos Ecossociais - PPP-ECOS) which is run by the Society, Population and Nature Institute (Instituto Sociedade, População e Natureza - ISPN).

To obtain a clearer vison of the results of that deforestation governance initiative in the settlement we analyzed the evolution of land use and settlement patterns with the help of satellite images as shown in the following section of the article.

\subsection{Land use evolution in the São Jorge settlement}

According to the data of the Incra's Agrarian Reform Projects Information System (Sistema de Informação de Projetos de Reforma Agrária - SIPRA), the São Jorge settlement currently has 95 beneficiaries. As remarked earlier, there is also a Collective Forest Reserve Area of 232.40 hectares established at the beginning of the occupation located near to the main village known as the Vila São Jorge I (Figure 2).

As the production activities of farming families have been transforming the settlement landscape over the last few decades. The analysis reported here refers to the period from 1990 to 2017. The data for the year 1990 portray dynamics prior to the creation of the settlement and those for 2000, 2010 and 2017 correspond to the dynamics established after the settlement came into existence (Figure 3 and Table 2). 
Figure 2: Map showing the location of the São Jorge settlement, Cidelândia/Maranhão.

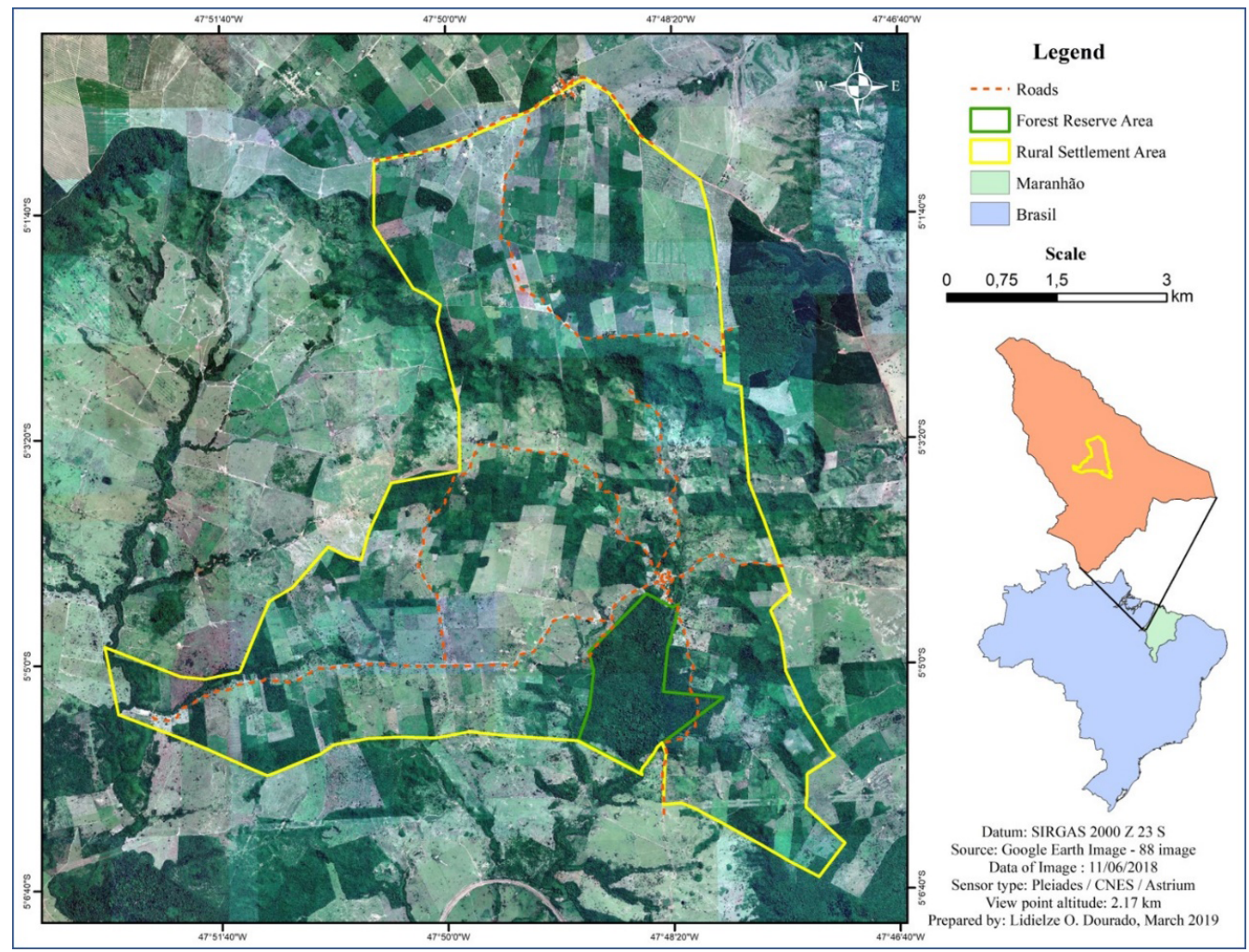

Source: Dourado et al. (2017).

Table 2 - Evolution of the participation of land use classes in the São Jorge settlement - 1990/2000/2010/2017.

\begin{tabular}{|l|l|l|l|l|l|l|l|l|}
\hline \multirow{2}{*}{ Classes/Year } & \multicolumn{2}{|l}{1990} & \multicolumn{2}{l}{2000} & \multicolumn{2}{l|}{2010} & \multicolumn{2}{l|}{2017} \\
\cline { 2 - 10 } & ha & $\%$ & ha & $\%$ & ha & $\%$ & ha & $\%$ \\
\hline Dense Vegetation & 990.1 & 20.45 & 596.48 & 12.32 & $1,118.4$ & 23.10 & $1,312.06$ & 27.10 \\
\hline Agricultural Area & $1,875.14$ & 38.73 & 684.11 & 14.13 & $2,253.75$ & 46.55 & $1,704.23$ & 35.20 \\
\hline $\begin{array}{l}\text { Areas in Regene- } \\
\text { ration }\end{array}$ & $1,412.28$ & 29.17 & $2,335.57$ & 48.24 & $1,254.45$ & 25.91 & $1,647.58$ & 34.03 \\
\hline Exposed soil & 543.22 & 11.22 & $1,144.54$ & 23.64 & 202.86 & 4.19 & 163.16 & 3.37 \\
\hline Bodies of Water & 20.82 & 0.43 & 80.85 & 1.67 & 12.1 & 0.25 & 14.52 & 0.30 \\
\hline
\end{tabular}

Source: Landsat Images 05 - 08, USGS.

The data analysis enabled the identification of two kinds of behavior in regard to the dense vegetation formation. From 1990 to 2000 it decreased, going from $20.45 \%$ of the total area to just $12.32 \%$. There are two explanations for that. The first is related to the process of the settler families establishing their first fields. The second is related 
to the effects of the forest fire of 1995 . From the year 2000 on the dynamics changed and there was an increase in dense vegetation area to $23.10 \%$ in 2010 and to $27.10 \%$ in 2017. According to the statements gathered in the field, that increment occurred mainly because of the recuperation of gallery forest and hilltop vegetation located in the southwest region of the settlement and to the maintenance of the ARFC.

Figure 3: Evolution of land use classes in the São Jorge settlement
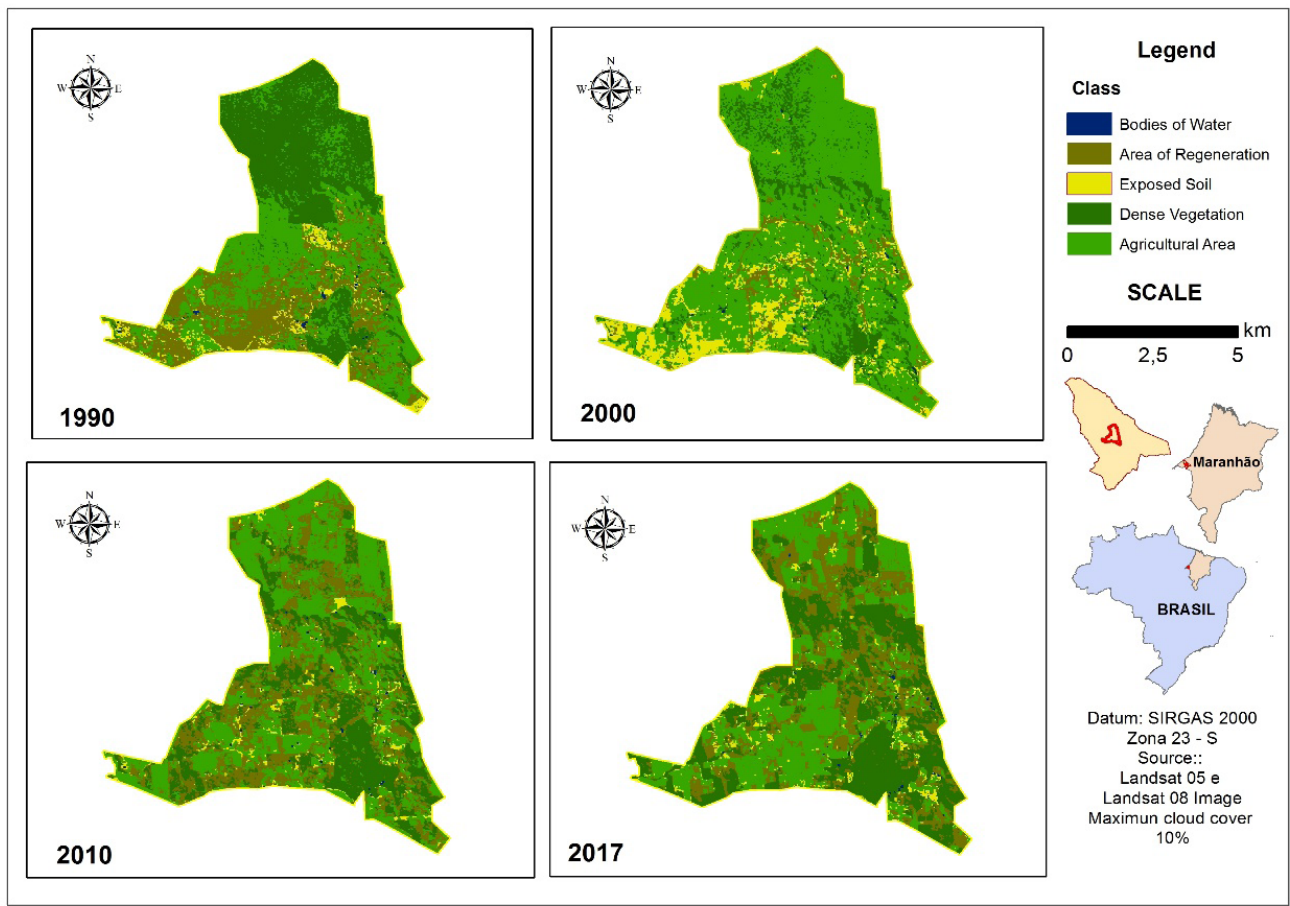

Source: Landsat Images 05 - 08, USGS.

The areas used for agricultural purposes performed differently. They reduced in the period from 1990 to 2000 even though it was the period in which the settlers' field areas were increasing. One explanation for that is that the area that was originally opened up for pastures was greater than the total area of the settler families' fields. It can be seen that from 2000 to 2010 there was a strong growth of the latter areas which came to account for almost half the settlement's vegetation cover. In the field we observed that it was a period in which there was a corresponding increase in the settlement's agricultural production. From 2010 to 2017, however, the area in agricultural use decreased. That is probably because of an increase in the areas left to lie fallow (areas in regeneration) and an increase in other landscape units such as permanent preservation areas and areas dedicated to perennial crop cultivation. 
In regard to the areas being prepared for crop cultivation (exposed soil) there was an observable overall reduction over the period of the study. An initial increase (1990 to 2000) was followed by a strong reduction (2000 to 2010). The initial increase could be explained by the combination of an accumulation of the areas cleared peior to the creation of the settlements and the increasing number of settlers' fields established in the settlement's early years. As for the reduction in the following period, the most likely explanation would be related to changes in agricultural practices and compliance with the environmental legislation, producing tangible effects in terms of the increase of protected areas and a reduction in the use of burning the vegetation as a technique for preparing the land.

\subsection{The skillful social actors and deforestation governance}

To analyze deforestation governance in the São Jorge settlement in an SAF perspective means it is necessary to observe how the settlers established the land use and occupation and how they managed to stabilize those rules as time went by, making adjustments and facing up to those who opposed them. In that regard Fligstein considers that to understand the stabilization of an SAF "it is necessary to verify the existence of a set of agreements that is maintained and which to a certain extent boosts the incumbents' power to achieve their objectives (FLIGSTEIN, 2011, p.178).

In the case of the São Jorge settlement, once again the roots of the process that constructed the land use and occupation rules were in the movement to occupy the area which was organized by the Imperatriz STTR and the CENTRU and included the formation of base production groups of families "that met to discuss and plan agricultural production according to their production aptitudes" (NÓBREGA, 2015). On a more general level, the stabilization of the settlement's land use and occupation rules was guaranteed by the organization created to represent the settlers, the Asprajorge.

According to one of the settlement's leaders, an important event helped to underscore the importance of maintaining the ARFC, a fire in 1995 that swept through most of the settlement area including the reserve.

$P:$ Were there any settlers against the collective reserve?

$R$ : Too many... There were colleagues against it but they lacked the courage to come out and say so, you see. Because the majority was already in favor of the reserve, within that [original] vision. That was in 1995 when we divided the land; that was when the great disaster struck. We divided up the land in September and in September there was such a great fire that almost nothing was left unburned. (Interview conducted with LG on November 25, 2012, Cidelândia).

However, in spite of that majority support for the maintenance of the ARFC, sometimes an internal agreement established among the settlers is not sufficient. In that case the settlement leaders need to call on external bodies of the State SAF, that is, the 
Incra or Ibama. That was what happened in the case of a settler who decided to make a field in the collective reserve area, in defiance of the Asprajorge orientation.

P. Aren't there any settlers who invade the collective reserve area?

R: No, no. Once there was a settler who made a field there, but he came off the worse for it; and that was the first threat I ever received. I denounced him to Ibama. I paid dearly for that but he paid dearly too. He went away. Sold his lot and went away (Interview conducted with L. G. on November 25, 2012, Cidelândia).

That excerpt of an interview is important not only because it underscores the importance of some state bodies in maintaining control of deforestation but also because it reveals a problem that is central to the reproduction of practical governance norms (DE SARDAN, 2008) in the settlements which is the high turnover rate of settlers albeit, in the case of the São Jorge settlement it is not so high as in other regions of the Amazon (AMARAL NETO et al., 2011). The ingress of other new farmers with different social trajectories and who had not participated in the process of conquest and occupation of the land questions the need to respect the rules of land use and occupation established by the original occupants.

In that regard it is worth highlighting the role Asprajorge played as a sphere of authority capable of maintaining the agreements and resolving conflicts, showing that it is indeed an entity that functions as an internal governance unit in the administration of the settlement. Made up of those settlers who participated in the successful struggle for the land, the legitimacy of the Asprajorge was forged on the basis of its ability to successfully address the settlers' needs and demands, namely, the application of agrarian reform credits and the solution of extant conflicts.

The demise of the partnership with the CENTRU due to the financial difficulties that beset the NGO strongly jeopardized the work of strengthening the agro-extractive activities and stimulating the implantation of the SAFs in the settlement. Currently the Asprajorge leadership has been seeking support for the development of those activities from other bodies and organizations such as the ISPN, the Federal University of Maranhão (UFMA) and the Brazilian Agricultural Research Corporation (EMBRAPA) in order to reinforce the established land use and occupation rules (DOURADO et al., 2017). 


\section{Conclusion: the challenges facing deforestation governance in the Amazon in different territorial scales}

The analysis presented in this article of experiences regarding the establishment of deforestation governance mechanisms in the Amazon underscores the importance of the role played by skillful social actors in constructing agreements that seek to conciliate the development of economic activities with respect for the environmental legislation.

The study of the São Jorge settlement enabled us to verify that the role was performed by leaders of the Asprajorge who, with the support of CENTRU, managed to construct a collective agreement among the settlers to establish and maintain an important collective forest reserve while at the same time undertaking actions to recuperate APPs in the settlement. In the case of Paragominas in Pará, the action of the skilled social actors was important in enabling the construction of the Paragominas: Green Municipality Project which, in a relatively short space of time, resulted in the removal of the municipality from the Deforestation Blacklist.

As Fligstein and McAdam (2012, p.17) explain, those skillful actors are crucial for the "creation of identities, the formation of political coalitions and the definition of collective interests" with a view to obtaining the cooperation of other actors to achieve certain objectives.

In the two processes, it was possible to observe the creation of internal governance units in such a way as to guarantee compliance with the established deforestation governance agreements. In the case of São Jorge settlement, that role of internal governance unit is carried out by the Asprajorge, whereas in Paragominas the same function is performed by the municipal Environmental Observatory; a forum created as part of the fulfillment of commitments made in the ambit of the State Green Municipalities Program (COSTA; FLEURY, 2015).

It must be stressed, however, that the existence of those internal units does not mean to say that those experiences have not been contested or that the standards of deforestation governance will be maintained in the long term. In the case of Paragominas for example, there are studies highlighting the absence of actions to support the environmental regularization of the family farmer's areas, and the exclusion of these actors from the main agreementss established in the ambit of the green municipality mobilization (VAZ et al., 2012; CARNEIRO, ASSIS, 2015; LAURENT et al., 2017)..

In the São Jorge experience, where the governance devices are less formalized than those in Paragominas, the established environmental agreements are mainly contested by those settlers that did not participate in the process of struggle for the conquest of the land and had no contact with the political qualification process conducted by the CENTRU and the Asrajorge to stimulate the development of agro-extractive practices and respect for the environment.

Another factor that may come to question the pattern of governance established in the settlement is the recent development of dairy farming and its demand for expansion of the areas of pasture especially on the part of farmers specializing in that type of 
economic activity (CARNEIRO et al., 2020).

Lastly, but by no means less importantly, we would highlight the contribution of the Theory of Strategic Action Fields to gaining an understanding of the deforestation governance processes in the Amazon (AMARAL, 2017; FRIZO, 2018) insofar as it develops, in a more profound way, the sociopolitical components of studies that have been made on that theme. In the case of deforestation governance studies, for example, it helps to qualify the idea that settlements with a strong social organization (ALENCAR et al., 2016) have a lower level of deforestation, showing the importance for the maintenance of practical governance rules of skillful social actors and their formation of coalitions with other actors situated in other fields, such as environmentalism (BUCLET, 2002; AMARAL, 2017) or the state.

Still, in the case of studies of the development of the PEMV, that kind of approach helps towards understanding the process of greater or lesser adherence on the part of the municipalities to the program goals, insofar as it brings to the foreground the role played by both incumbent and challenging actors in the local political/policy dynamics while at the same time underscoring the central role played by agents situated in other action fields such as representatives of NGOs and of State agencies (CARNEIRO; ASSIS, 2015; FRIZO, 2018).

\section{Acknowledgements}

We wish to thank the National Council for Scientific and Technological Development (Conselho Nacional de Desenvolvimento Científico e Tecnológico - CNPQ) and the Research Support Foundation of Maranhão (Fundação de Amparo à Pesquisa do Maranhão - FAPEMA) for financing this research and the Association of Rural Smallholders of the São Jorge Settlement (Pequenos Produtores Rurais do Assentamento São Jorge - ASPRAJORGE) for the support given during the field work.

\section{References}

ALENCAR, Ane et al. Desmatamento nos assentamentos da Amazônia: histórico, tendências e oportunidades. Instituto de Pesquisa Ambiental da Amazônia. Brasília. 2016. Available at: $\quad<$ http://ipam.org.br/wp-content/uploads/2016/02/Desmatamento-nos-Assentamentos-da-Amaz\%C3\%B4nia.pdf>. Consulted on: July 5, 2018.

ALMEIDA, Oriana (Org.) A evolução da fronteira amazônica: oportunidades para um desenvolvimento sustentável. Belém: Imazon, 1996.

AMARAL Roberta. Legalização da produção madeireira na Amazônia brasileira: análise do manejo florestal comunitário em uma perspectiva do campo de ação estratégica. 2017. 134 f. 
Dissertation (MSc in Production Engineering) - Programa de Pós-Graduação em Engenharia da Produção, Universidade Federal de São Carlos, São Carlos, 2017.

AMARAL NETO, Manuel et al. Análise dos acordos entre empresas e comunidades para a exploração florestal madeireira em assentamentos rurais na região da BR 163, no estado do Pará. Belém: IEB, 2011.

BARRETO, Paulo; ARAÚJO, Elis. O Brasil atingirá sua meta de redução do desmatamento? Belém: Imazon, 2012.

BARROS, Betina. Certificação de propriedades trava e já tem 20 mil na fila. Valor Econômico, São Paulo, 16 abr. 2012, Caderno B, p.16.

. O desafio da sustentabilidade na Amazônia. Valor Econômico, São Paulo, 11-13 jun. 2010, Caderno B, p. 16.

BOURDIEU, P. Les structures sociales de l'économie. Paris: Ed. du Seuil, 2000.

BUCLET, Benjamin. Les expérimentations des ONGs en Amazonie: quel pouvoir pour quelle responsabilité? Lusotopie, n. 1, p. 263-282, 2002.

CARNEIRO, Jonatha F; CARNEIRO, Marcelo S; LIMA NETO, Evaristo J. O desenvolvimento da agricultura familiar e sua inserção na cadeia produtiva do leite na região de Imperatriz: principais características e desafíos socioeconómicos. Agricultura Familiar: Pesquisa, Formação e Desenvolvimento, v. 14, n.1, p.75-100, jun. 2020.

CARNEIRO, Marcelo Sampaio. Convenções de qualidade e a inserção da agricultura familiar na cadeia produtiva do leite na região de Imperatriz/MA. Sinais Sociais, v. 10, p. 129-149, 2015.

CARNEIRO, Marcelo Sampaio; ASSIS, William Santos. O controle do desmatamento na Amazônia como um processo de modernização ecológica: a experiência do Projeto Município Verde. Revista Pós Ciências Sociais, v. 12, p. 53, 2015.

CEPAL/IPEA/GIZ. Avaliação do Plano de Ação para Prevenção e Controle do Desmatamento na Amazônia Legal, PPCDAm 2007-2010. CEPAL/IPEA/GIZ: Brasília, 2011.

COSTA, Jodival Maurício; FLEURY, Marie-François. O Programa "Municipios Verdes": estratégias de revalorização do espaço em municípios paraenses. Ambiente $\mathbb{\&}$ Sociedade, v. XVIII, n. 2, p. 61-76, 2015. Available at: < http://www.scielo.br/pdf/asoc/v18n2/pt_1414-753Xasoc-18-02-00059.pdf $>$. Consulted on: August 10, 2018.

DE SARDAN, Jean-Pierre Olivier. Researching the practical norms of real governance in África. London: DFID, 2008. (Discussion paper, n】5). Available at: <http://www.institutions-africa.org/filestream/20090109-discussion-paper-5-researching-the-practical-norms-of-real-governance-in-africa-jean-pierre-olivier-de-sardan-jan-2009>. Consulted on: August 10, 2018.

DEMARCHKI, Adnan; ZAGALO NETO, Armindo F. Paragominas no contexto amazônico. Revista de Estudos Paraenses (IDESP), v.1, n.3, p. 111-123, 2008. 
DOURADO, Lidielze et al. O desmatamento e as estratégias de agricultores familiares do projeto de assentamento São Jorge frente as exigencias da nova legislação ambiental. In: VIII SIMPÓSIO INTERNACIONAL DE GEOGRAFIA AGRÁRIA E IX SIMPÓSIO NACIONAL DE GEOGRAFIA AGRÁRIA. 2017. Curitiba. Anais eletrônicos... Rio de Janeiro. Available at: $<$ https://singa2017.files.wordpress.com/2017/12/gt05_1504573329_arquivo_artigocompletosinga.pdf $>$. Consulted on: August 10, 2018.

FERNANDES, Roberta Aviz Brito. Discursos de sustentabilidade: o caso de Paragominas. 2011. 92 f. Dissertation (MSc in InformationScience) -Programa de Pós-Graduação em Ciências da Informação. Universidade Federal do Rio de Janeiro, Rio de Janeiro, 2011.

FLIGSTEIN, Neil. Teoria e métodos para o estudo de campos de ação estratégica. In: DONADONE, J.C.; JARDIM, M.A.C (Orgs.) As centralidades e as fronteiras das empresas no século 21. Bauru: EDUSC, 2011. p.157-214.

FLIGSTEIN, N.; MCADAM, D. A theory of fields. New York/Oxford: Oxford University Press, 2012.

FRIZO, Pedro G. A. Os fundamentos institucionais para o gerenciamento dos bens comuns na Amazônia Central. 2018. 311 f. Dissertation (MSc in Sociology) - Programa de Pós-Graduação em Sociologia, Universidade Federal do Rio grande do Sul, Porto Alegre, 2018.

INSTITUTO INTERAMERICANO DE COOPERAÇÃO PARA A AGRICULTURA/IICA. Plano de Consolidação dos Projetos de Assentamento São Jorge e Itaiguara - Relatório Final. Diagnóstico - Volume I. São Luís: IICA, 2006.

INPE. Monitoramento da Floresta Amazônica por satélites - sistema PRODES: Dados por município. São José dos Campos: Instituto Nacional de Pesquisas Espaciais - INPE, 2008. Available at: < http://www.dpi.inpe.br/prodesdigital/prodesmunicipal.php>. Consulted on: August 10, 2018.

KOWARICK, Marcos Alexandre. A política ambiental de reserva legal em assentamentos rurais da Amazônia maranhense. 2011. 156 f. Dissertation (MSc in Sustainable Development) - Centro de Desenvolvimento Sustentável. Universidade de Brasília, Brasília, 2011.

LASCOUMES, Pierre; LE GALÈS, Patrick. Sociologie de l'action publique. Paris: Armand Colin, 2009.

LAURENT, François et al. Le tournant environmental en Amazonie : ampleur et limites du decouplage entee production et deforestation. EchoGéo [OnLine], v.41, 2017. Available at: <https://journals.openedition.org/echogeo/15035>. Consulted on: August 20, 2018.

LIMA, André; CAPOBIANCO, João Paulo; MOUTINHO, Paulo. Desmatamento na Amazônia: medidas e efeitos do Decreto Federal 6.321/07. Belém: IPAM, 2008. Available at: <http:/www.ipam.org.br/biblioteca/livro/Desmatamento-na-Amazonia-Medidas-e-efeitos-do-Decreto-Federal-6-321-07/62>. Consulted on: November 10, 2012.

LUCENA, Solange L. É possível desenvolver respeitando o meio ambiente? Estudo de caso da experiência do município de Paragominas - Pará. 2011. Final Course Paper 
(Specialization in Auditing Municipal Environmental Management) - Núcleo de Meio Ambiente, Universidade Federal do Pará, Belém, 2011.

PROJETO MAPBIOMAS - Coleção 4.0 da Série Anual de Mapas de Cobertura e Uso de Solo do Brasil, acessado em 20 de Dezembro de 2019 através do link: https://mapbiomas.org/.

MICHELETTI, Michele. Le consumérisme politique: une nouvelle forme de gouvernance transnationale? Sciences de la Société, n. 62, p. 119-144, 2004.

NEPSTAD, Daniel et al. A globalização das indústrias da soja e do gado na Amazônia: oportunidades para a conservação. In: RIVERO, S.; JAYME JR., F.G (Orgs.) As Amazônias no século XXI. Belém: EDUFPA, 2008, p. 41-66.

NÓBREGA, Mariana Leal Conceição. Enfrentando a sucuri verde: resistência camponesa e o território de uso comum - o caso das comunidades agroextrativistas na Amazônia maranhense. 2015. 207 f. Dissertation (MSc in Geography) - Instituto de Geociências, Universidade Estadual de Campinas, Campinas, 2015.

PAUGAM, Serge; VAN DE VELDE, Cécile. O raciocínio comparatista. In: PAUGAM, S. (Coord.). A pesquisa sociológica. Petrópolis: Vozes, 2015, p.290-304.

SANTOS, Manuel da Concieção. Chão de minha utopia. Belo Horizonte: Editora da UFMG, 2010.

SAUER, Sérgio. Prevenção de incêndios florestais na Amazônia: lições aprendidas no Projeto Proteger. Brasília: Ministério do Meio Ambiente, 2005. (Série Estudos, n. 1).

SOUSA, Larissa Melo et al. Avaliação do uso e cobertura da terra em Paragominas e Ulianópolis, utilizando dados do Projeto Terraclass. Revista Brasileira de Cartografia, v. 3, n. 69, p. 421431, 2017. Available at: < file:///C:/Users/user/Contacts/Downloads/44339-Texto\%20do\%20artigo-184269-1-10-20180904\%20(1).pdf>. Consulted on: August 10, 2018.

SILVA, Laryssa Cássia Tork et al. Mapeamento do uso e cobertura da terra em áreas desflorestadas no município de Paragominas/PA nos anos de 1991 e 2008. In : XV SIMPOSIO BRASILEIRO DE SENSORIAMENTO REMOTO. 2017. Curitiba. Anais eletrônicos... Curitiba, p.6658-6665. Available at: < http://marte.sid.inpe.br/col/dpi.inpe.br/marte/2011/07.12.12.09/ doc/p1206.pdf>Consulted on: August 10, 2018.

USGS. Science for a changing World. NASA. Landsat Product Type. 2010. Available at: <USGS. Science for a changing World. NASA. Landsat Product Type>. Consulted on: August 10, 2018.

VAZ, Vânia et al. A pecuária na agenda ambiental da Amazônia brasileira: percepções e representações dos atores locais. In: ALMEIDA, J. GERHARDT, C., MAGALHAES, S.B. (Orgs.) Contextos rurais e agenda ambiental no Brasil: práticas, políticas, conflitos e interpretações. Belém: Rede de Estudos Rurais, 2012, p. 65-90. 
Marcelo Sampaio Carneiro

ఐjmdscarneiro@uol.com.br

ORCiD: http://orcid.org/0000-0002-7474-2694
Submitted on: 22/09/2018

Accepted on: 25/05/2020

2020;23:e02472

\section{William Santos Assis}

ఐwilliamassis@ufpa.br

ORCiD: https://orcid.org/0000-0002-9525-7153

\section{Ulisses Denache Vieira Souza}

$\square$ ulissesdenache@gmail.com

ORCiD: https://orcid.org/0000-0002-4964-9017

\section{Lidielze Dourado}

$\square$ leydedourado@hotmail.com

ORCiD: https://orcid.org/0000-0002-9332-0892

How to cite: CARNEIRO, M S.; ASSIS, W.S.; SOUZA, U. D V.; DOURADO, L. Deforestation governance in the Amazon from a Strategic Action Fields perspective. Ambiente $\&$ Sociedade. São Paulo, v. 23, p. 1-22, 2020. 


\title{
A governança do desmatamento na Amazônia na perspectiva dos Campos de Ação Estratégica
}

\author{
Marcelo Sampaio Carneiro \\ William Santos Assis \\ Ulisses Denache Vieira Souza \\ Lidielze Dourado
}

São Paulo. Vol. 23, 2020

Artigo Original
Resumo: Este artigo tem por objetivo analisar o desenvolvimento de ações de governança do desmatamento na Amazônia, a partir da análise de dois estudos de caso, utilizando a teoria dos campos da ação estratégica (FLIGSTEIN; MCADAM, 2012). Nesse sentido, analisamos a experiência de mobilização pela retirada do município de Paragominas/ PA da lista suja do desmatamento, e o desenvolvimento de ações de controle do desmatamento no assentamento São Jorge, no município de Cidelândia/MA. Para realizar esta análise, utilizamos informações obtidas a partir de entrevistas com atores centrais nos dois casos estudados e trabalhamos com a análise de imagens de satélite. Os resultados obtidos indicam a pertinência da utilização da teoria dos campos de ação estratégica para a compreensão de processos de governança do desmatamento na Amazônia, destacando a importância de conceitos centrais a essa teoria, como a atuação de atores sociais habilidosos e a construção de unidades internas de governança.

Palavras-chave: Desmatamento; Governança; Campos de Ação Estratégica; Amazônia.

Como citar: CARNEIRO, M S.; ASSIS, W.S.; SOUZA, U D. V.; DOURADO, L. A governança do desmatamento na Amazônia na perspectiva dos Campos de Ação Estratégica. Ambiente $\&$ Sociedade. São Paulo, v. 23, p. 1-22, 2020. 


\title{
Gobernando la deforestación en la Amazonía desde la perspectiva de los Campos de Acción Estratégica
}

\author{
Marcelo Sampaio Carneiro \\ William Santos Assis \\ Ulisses Denache Vieira Souza \\ Lidielze Dourado
}

São Paulo. Vol. 23, 2020

Artículo original
Resumen: Este artículo tiene por objetivo analizar el desarrollo de las acciones de gobernanza de la deforestación amazónica, utilizando la teoría de los campos de acción estratégica (FLIGSTEIN; MCADAM, 2012). En ese sentido, analizamos la experiencia de movilización de retirada del municipio de Paragominas/PA de la lista sucia de la deforestación y el desarrollo de las acciones de control de la deforestación en el asentamiento São Jorge, en el municipio de Cidelândia/MA. Para este análisis, empleamos informaciones obtenidas en entrevistas con actores centrales de los casos estudiados y el análisis de imágenes satelitales. Los resultados conseguidos indican el uso eficaz de la teoría de los campos de acción estratégica para la comprensión de procesos de gobernanza de la deforestación amazónica, destacando la importancia de los conceptos centrales de esa teoría, como la actuación de los actores sociales habilidosos y la construcción de unidades internas de gobernanza.

Palabras-clave: Manglares; Deforestación; gobernanza; Campos de Acción Estratégica; Amazonía.

Como citar: CARNEIRO, M S.; ASSIS, W.S.; SOUZA, U D. V.; DOURADO, L. Gobernando la deforestación en la Amazonía desde la perspectiva de los Campos de Acción Estratégica. Ambiente \& Sociedade. São Paulo, v. 23, p. 1-22, 2020. 